\title{
Extraordinary Remaining Potential in the Pre-Salt of Santos Basin
}

\author{
Pedro Victor Zalán, ZAG Consultoria em Exploração de Petróleo Ltda., Rio de Janeiro
}

Karyna Rodriguez, SPECTRUM Geo, London, UK

Milos Cvetkovic, SPECTRUM Geo, Houston, USA

\section{Copyright 2019, SBGf - Sociedade Brasileira de Geofísica}

This paper was prepared for presentation during the $16^{\text {th }}$ International Congress of the Brazilian Geophysical Society held in Rio de Janeiro, Brazil, 19-22 August 2019.

Contents of this paper were reviewed by the Technical Committee of the $16^{\text {th }}$ International Congress of the Brazilian Geophysical Society and do not necessarily represent any position of the SBGf, its officers or members. Electronic reproduction or storage of any part of this paper for commercial purposes without the written consent of the Brazilian Geophysical Society is prohibited.

\section{Abstract}

The Pre-Salt of the Santos and Campos Basins in Southeastern Brazil is a remarkable, world-class petroleum province. First discovery took place in 2006 and first production in 2008. Ten years in a row and production by the end of 2018 was 1,9 MMboepd, being 1,5 MMbopd from 85 wells only. The landmark of 1 MMbopd was achieved after 8 years of production. Cumulative production is over 2 billion barrels. Forty wells produced more than 20 Mbopd, with peaks of $42-45$ Mbopd. One field alone, Tupi Field, produces 897 Mbopd. More than half $(56 \%)$ of the Brazilian production of hydrocarbons nowadays comes from the Pre-Salt. Three fields (Tupi, Búzios and lara Complex) can be classified as super-giants while four others are giant fields (Parque das Baleias, Mero, Sapinhoá, Lapa). Known discoveries are candidates for the super-giant (Carcará) and giant (Sagitário) status. Recently leased blocks contain very large prospects that are such candidates as well.

Two-dimensional seismic surveys shot by Spectrum in the distal portions of the wide continental margins of the São Paulo Plateau (encompassing the Santos and Campos Basins), well beyond the producing fields (Figure 1), had unveiled previously unknown giant four-way closed structures presenting very favorable buildup seismic facies at the Pre-Salt reservoir level. The reservoirs are constituted by carbonate rocks generically called microbialites. The best reservoirs in the microbialite realm are the buildup facies. Such huge pyramidal constructions, seismically transparent to chaotic, are made mainly of travertine/tufa deposits fed by hydrothermal solutions that percolated through normal faults lying underneath the buildups (Zalán, 2013) (Figure 2 ). Since these faults cut and controlled shallow hypersaline lakes, where bacteria thrived and deposited extensive platforms of mats, the travertine buildups present mixed abiotic-biotic carbonate rocks in their composition.

The structures mapped range from huge clusters of structural closures (Xavante Complex, in the order of $4000 \mathrm{~km}^{2}$, Puri Complex, circa $2950 \mathrm{~km}^{2}$ ) to individual structures varying from $1200 \mathrm{~km}^{2}$ to $150 \mathrm{~km}^{2}$. All these structures are situated either upon the southwest/southern extension of the External High, the expression of a Continental Resistate; or to the east of this important tectonic feature, upon hyper-extended crust. Practically all of the known Pre-Salt accumulations have been sourced from the Internal Kitchen grabens, situated upon the depressed thinned/hyper-extended continental crust lying between the Cretaceous hingeline and the External High (Figure 3). These newly detected Pre-Salt prospects, as most of the recently leased blocks, will depend upon the existence of an External Kitchen to the east of the External High, developed upon thinned and hyper-extended crust. These new seismic sections indicate the presence of significant Pre-Salt grabens, but displaying slightly lesser thicknesses than those at the Internal Kitchen. Thus, the risk associated to these structures is the existence of rich source rocks in the External Kitchen, similar to those in the Internal Kitchen. The other elements of the Pre-Salt petroleum system (migration, closure, reservoir, seal and timing) seem to be obviously present in the seismic sections. The size of the structures and their vertical relief, especially on those constituted by buildups, do not allow them to pass unnoticed to and undrilled by the petroleum industry.

\section{Pre-Salt Petroleum System 1 - The Internal Kitchen -}

The presently known prolific Pre-Salt petroleum system is sourced from syn-rift organic-rich shales of Late Barremian to Early Aptian age (Brazilian local Jiquiá age) that occur in both the Campos and Santos Basins. They occur in the inner portions of the basins, in the upper parts of grabens that are situated between a huge structural high trend termed External High and the Cretaceous hingeline (Figure 3 ). These shales had been drilled, sampled and analyzed by several Petrobras exploratory wells, mostly in the Campos Basin, a few in the Santos Basin. They are usually interlayered with coquina levels and their thicknesses are in the order of several tens of meters. The geochemical markers of their yielded oils characterize saline to brackish water lacustrine depositional environments. Practically all the known accumulations of oil in the Pre-Salt of the Santos and Campos Basins are derived from such shales. As a matter of fact, all Post-Salt accumulations in the Campos Basin situated upon and to the west of the External High are also derived from these shales. Thus, the term Internal Kitchen is used to designate these inner grabens and their syn-rift saline to brackish water organicrich shales of Late Barremian to Early Aptian age (Brazilian local Jiquiá age). 


\section{The Importance of the External High for the Pre-Salt} Petroleum System -

The External High is long and wide, continuous trend of structural highs that runs along the Campos and Santos Basins in N-S-direction (Campos) and NE-SW-direction (Santos), cutting these basins "in the middle" (Figure 3). The External High is the surface expression of a continental crust resistate that presents a deep Moho underneath it and a significant larger crustal thickness than the surrounding thinned and hyper-extended areas of continental crust (Figure 4). It divides the Campos and Santos Basins into an inner narrow and an external wider depressed areas, where grabens were developed upon much thinner stretched and hyper-extended crust. This crustal geometry developed during the rift phase (extension/thinning/rupturing) that affected this area of the Gondwana supercontinent. The different crustal thicknesses possibly reflect different Precambrian terrains, whose trends are similar to Precambrian terrains exposed in the coastal zone of Southeastern Brazil (Araçuaí, Ribeira and Tijucas orogenic belts of the Mantiqueira Province; Hasui,2012). These old terrains had significantly different compositions, and probably acted/reacted in different ways to extension during the rifting process. Some were more plastic and stretched and thinned, and even broke up, more easily; constituting at the end the stretched/thinned and hyper-extended terrains. Others were more stiff and resisted extension maintaining their crustal thicknesses close to original; forming at the end the continental resistate. The External High floats isostatically amidst the adjacent thinner terrains (see Figure 6 of Zalán et al., 2011).

This geometry of a central high flanked by deeper areas is highly favorable for focusing of migration. Hydrocarbons generated in the depressed areas would migrate towards this central high. The load of immense piles of clastic sediments (Juréia Fm.; Moreira et al., 2007), shed from the adjacent (to the west) rapidly rising Cretaceous Serra do Mar during the ConiacianMaastrichtian (Zalán and Oliveira, 2005) tilted the External High to the west, enhancing even more the tendency for the hydrocarbons generated in the Internal Kitchen to migrate towards its highest culminations (e.g.: Tupi Field). Figuratively speaking, the External High acts like the backbone of the Campos and Santos Basins, displaying on both sides the flattened downwards ribs. The inner, proximal rib cage represents the Internal Kitchen. The outer, distal rib cage represents the External Kitchen (Figure 3).

\section{The Pre-Salt Petroleum System 2 - The External Kitchen -}

The new 2D seismic sections were shot predominantly over the southern extension of the External High and of the largely unchartered terrain to the east of it. They were able to demonstrate that the known mapped portion of the External High in the Santos Basin (to the south of the Sapinhoá and Lapa Ring Fences), that runs along a NESW-trend coming from the Campos Basin, makes an abrupt turn to the southeast and extends towards the Florianópolis Oceanic Fracture Zone, where it turns to the east and becomes parallel to this OFZ (Figure 3). Experience recommends that once you have a prolific trend of oil discoveries its newly mapped continuation should become a primary target for further exploration.

The seismic sections also revealed a promissing External Kitchen. The continental crustal terrains situated to the east of the External High are predominantly situated over hyper-extended crust. Several grabens, some with significant thicknesses (up to $3000 \mathrm{~m}$ ), can be clearly seen far out to the east of the External High. Seismic facies are sometimes very similar to the ones known in the Internal Kitchen (Figure 4), pointing to a similar sedimentary fill. Caution should be prompted, however, because, in a general way, such grabens are less abundant and thinner than in the Internal Kitchen. In the more external reaches of the hyper-extended crust the seismic facies within the grabens may differ significantly, raising the red flag of possible volcanic filling. The abundance of syn-rift volcanic edifices throughout this area seems to point to an environment of sparse shallow lakes of high alkalinity, surrounded by active volcanos.

As it will be seen in the next chapter, the only item of the Pre-Salt petroleum system in this outer region that presents a sizable risk is the occurrence, abundance and organic-richness of shales in these grabens. Qualitatively speaking, the Pre-Salt petroleum system in the External Kitchen can be considered a proven petroleum system. The occurrence of gas/oil in Repsol's discoveries in BMC-33 and Devon's oil discovery in BM-C-34 had been geochemically traced to lacustrine shales from the External Kitchen that are slightly different in terms of paleoenvironments from those in the Internal Kitchen. The quantitative proof for profitability remains to be tested by further drilling.

\section{The Newly Mapped Prospects -}

The mapping of the Base of the Salt reflector in the lines of the SAN CAM Phases 1, 2, 3 two-dimensional survey shot by Spectrum revealed 21 structural closures varying in area from $1200 \mathrm{~km} 2$ to $150 \mathrm{~km} 2$. These prospects consist of:

(1) Four-way closures related to horst blocks upon which carbonate platforms were developed. Inside such platforms microbialites tend to follow the carbonate ramp depositional model. They can display high-energy shallow shelf facies, clinoforms and low-energy basinal facies (Figure 5). Frequently, medium to large buildup facies, related to underlying faults, can be recognized scattered throughout the platform.

(2) Three-way closures related to fault-related rotated blocks, similar to Tupi Field (Figure 6). In this case, the microbialites seismic facies also follow the carbonate ramp depositional model.

(3) Four-way closures of relatively smaller areas (when compared to the 2 types described above) but with huge vertical reliefs. The cores of such prospects invariably present chaotic or transparent seismic facies suggesting huge travertine/tufa buildups related to underlying faults. 
Their shapes can be pyramidal, conical, elliptical, mound to highly irregular (Figure 7).

Besides the closures mapped in a regular $10 \mathrm{~km} \times 10 \mathrm{~km}$ seismic grid and the favorable reservoir seismic facies, these prospects present abundant sealing (the whole mapped area is covered by a continuous and abundant salt layer) and abundant routes for migration (faults, Figures 5-7). Since the External Kitchen is a syn-rift feature developed mostly upon thin to very thin stretched and hyper-extended continental crust, maturation of the possible source rocks was probably attained by the end of the rift phase. Rifting in this outermost area of the Santos Basin started late (Barremian-Early Aptian) but lasted until the end of the salt deposition (112 Ma, Earlymost Albian) (Zalán, 2016).

\section{Conclusions}

The remaining potential of the Pre-Salt in the Santos Basin seems to be extraordinary! Huge structural closures situated along the southern extension of the External High as well as inside the External Kitchen, displaying favorable microbialite reservoir facies, abundant sealing and intense faulting point to probable discoveries of several super-giant and giant oil/gas fields in the future. By a rough comparison between the sizes of these structures and known producing fields in the Santos Basin a risked Prospective Resource of 20-30 Gboe can be estimated to be hidden in these prospects.

\section{References}

Hasui, Y., 2012, Sistema Orogênico Mantiqueira, in Hasui, Y., Dal Ré Carneiro, C., Almeida, F.F.M., Bartorelli, A., eds., Geologia do Brasil. Beca, São Paulo, p.331-371.

Moreira, J.L.P., Madeira, C.V., Gil, J.A., Machado, M.A.P., 2007. Bacia de Santos. Boletim de Geociências da Petrobras, v. 15 , no. 2 , Maio/Nov p. 531-549, Rio de Janeiro.

Zalán, P.V. \& Oliveira, J.A.B., 2005, Origem e Evolução Estrutural do Sistema de Riftes Cenozóicos do Sudeste do Brasil. Boletim de Geociências da Petrobras, v. 13, no. 2, Maio/Nov., p. 269-300, Rio de Janeiro.

Zalán, P.V., Severino, M.C.G., Rigoti, C., Magnavita, L.P., Oliveira, J.A.B., Viana, A.R., 2011, An Entirely New 3Dview of the Crustal and Mantle Structure of a Ruptured South Atlantic Passive Margin - Santos, Campos and Espírito Santo Basins, Brazil, AAPG Search and Discovery Article \#30177, AAPG Annual Convention 2011, Houston, Texas, April 10-13, 12 p. (Expanded Abstract)

Zalán, P.V., 2013, Tectonic controls on very thick and laterally confined microbialites in the pre-salt petroleum system of the South Atlantic, AAPG Search and Discovery Article \#90163, AAPG Annual Convention 2013, Pittsburgh, Pennsylvania, May 19-22.

Zalán, P.V., 2016, Temporal and Spatial Evolution of Rifting in the Brazilian Southeastern Passive Margin,
AAPG Search and Discovery Article \#90259, AAPG Annual Convention 2016, Calgary, Canada, June 19-22 (Abstract).

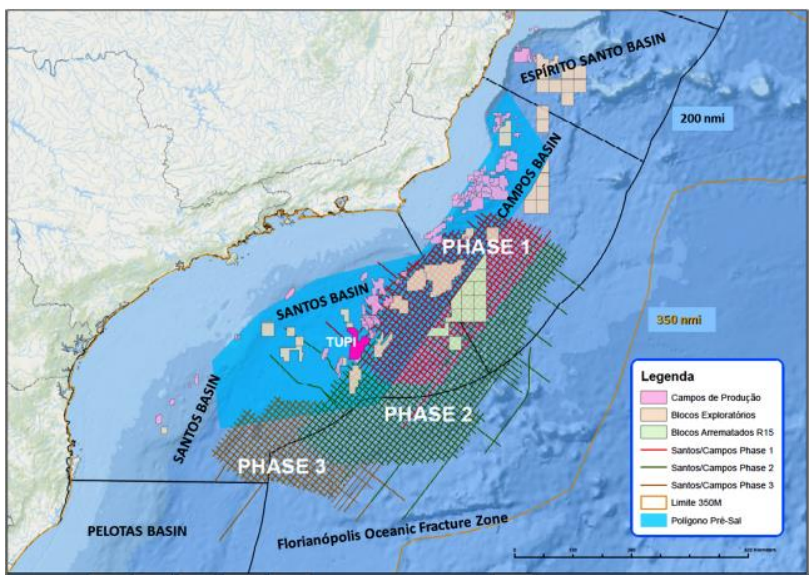

Figure 1 - Index map of the SAN CAM Ph 1 (red), 2 (green), 3 (brown) 2Dsurveys. Grid is $10 \mathrm{~km} \times 10 \mathrm{~km}$. All leased blocks and Ring Fences, the $200 \mathrm{nmi}$ EEZ line, the $350 \mathrm{nmi}$ line and the Pre-Salt Polygon (turquoise) are also shown for reference, as well as the geographic boundaries between the Espírito Santo, Campos, Santos and Pelotas Basins.

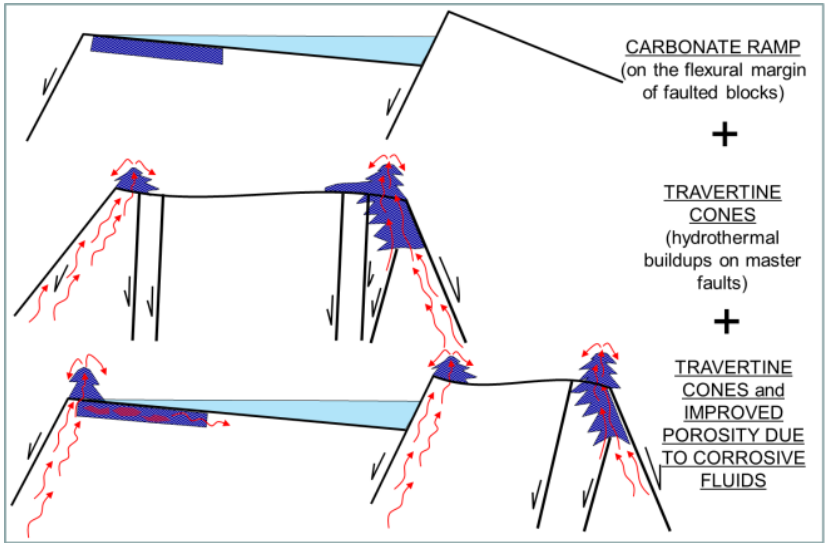

Figure 2 - Depositional models considered in this work for the mapping of optimal microbialite reservoir facies in seismic sections. First model depicts the typical carbonate ramp model, universal for most types of carbonate deposition. Best reservoir facies (dark blue) develop in the flexural flank of syn-rift rotated fault blocks, where the higher energy of waves promote the nurturing and oxygenation necessary for the growth of stromatolite heads (shrubs). Second model illustrates the formation of conical-shaped buildups of travertine/tufas related to hydrothermal vents, by fluids that flowed along normal faults of the rift phase. Third model is a mix of the two models where the percolating fluids enhance the porosity of older microbialite high-energy and buildup reservoirs. Notice in the last model the construction of anomalously high travertine/tufa buildups in shallow lakes. 


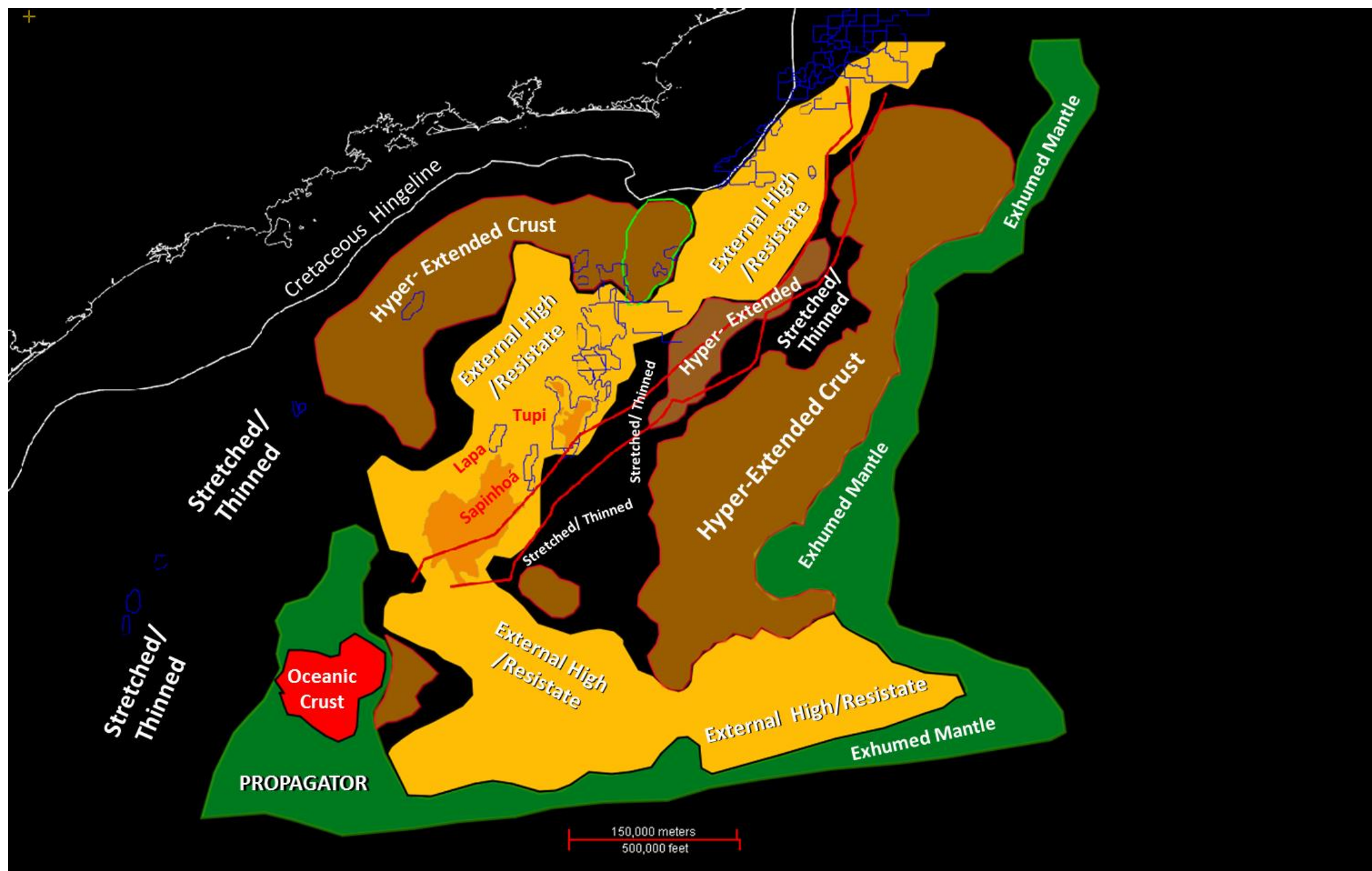

Figure 3 - Map of the crustal domains in the Santos Basin obtained from the interpretation of SAN CAM Phs 1, 2, 3. The continental crust underneath the Santos Basin extends from the Cretaceous hingeline out to the border of the belt of Exhumed Mantle. Three main continental crustal domains are recognized: Stretched/Thinned, where the crust is moderately thinned and the brittle and ductile crusts are still discernible; Continental Resistate, where the crustal thickness is close to original; Hyper-Extended, where the crust is so thinned that the upper brittle and lower ductile crusts are indiscernible and both underwent brittle deformation during the rift phase. The External High is the surficial expression (at the Basement and Base of Salt levels) of a throughgoing Continental Resistate. The Internal Kitchen lies between the External High and the Cretaceous hingeline. The External Kitchen is situated between the External High and the Exhumed Mantle, sitting mostly upon Hyper-Extended Crust. The Propagator is a V-shaped wedge of Exhumed Mantle upon which a small layer of oceanic crust was developed and aborted. 

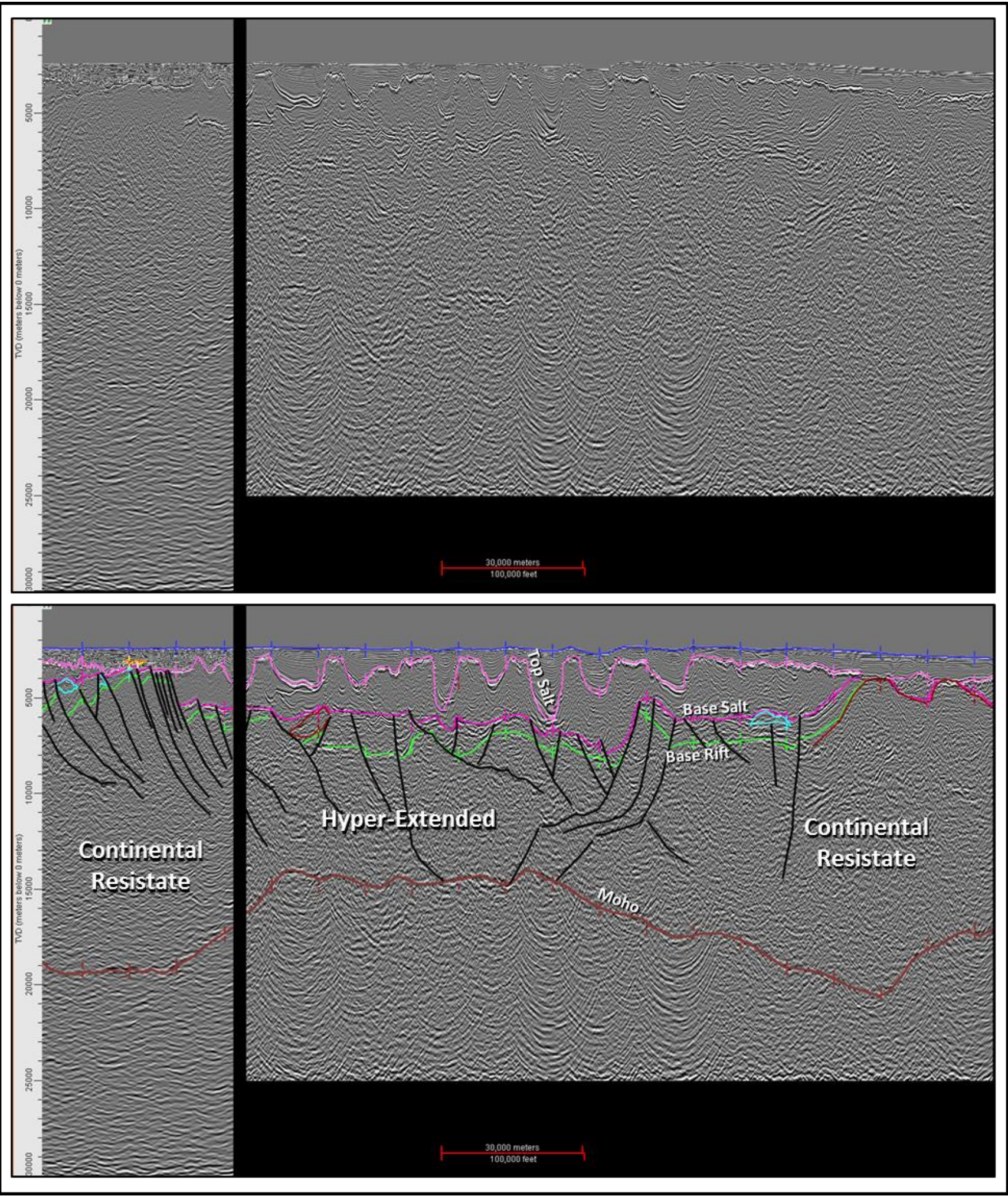

Figure 4 - Depth seismic section displaying continental crustal domains. The External High, the surficial expression of a Continental Resistate, is seen twice in this section. In the middle, a nice example of Hyper-Extended crust displaying very thick salt deposits and sizeable Pre-Salt grabens that may constitute the External Kitchen. 

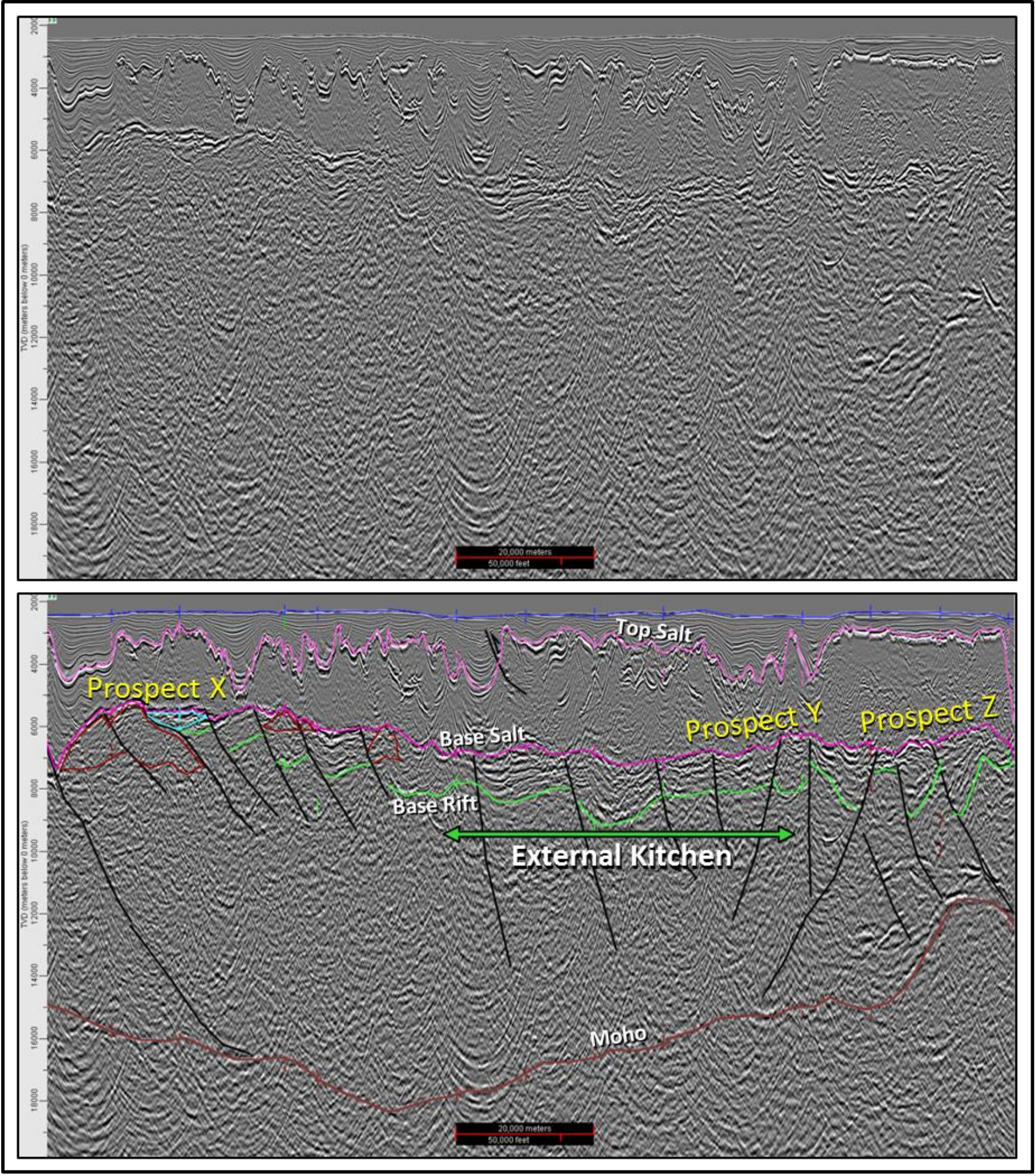

Figure 5 - Depth seismic section displaying a large four-way closure related to a horst block (Prospect X) and two other smaller fault-related four-way closures. The reservoir seismic facies in these prospects, right below the Base of Salt,display layered, parallel and continuous mild to strong reflections. These seismic facies are interpreted to represent microbialite strata deposited according to the carbonate ramp model (see Figure 2). In the center, a large graben filled by sedimentary strata that closely resemble grabens of the Internal Kitchen could indicate a potential External Kitchen graben that could fill all three prospects. 

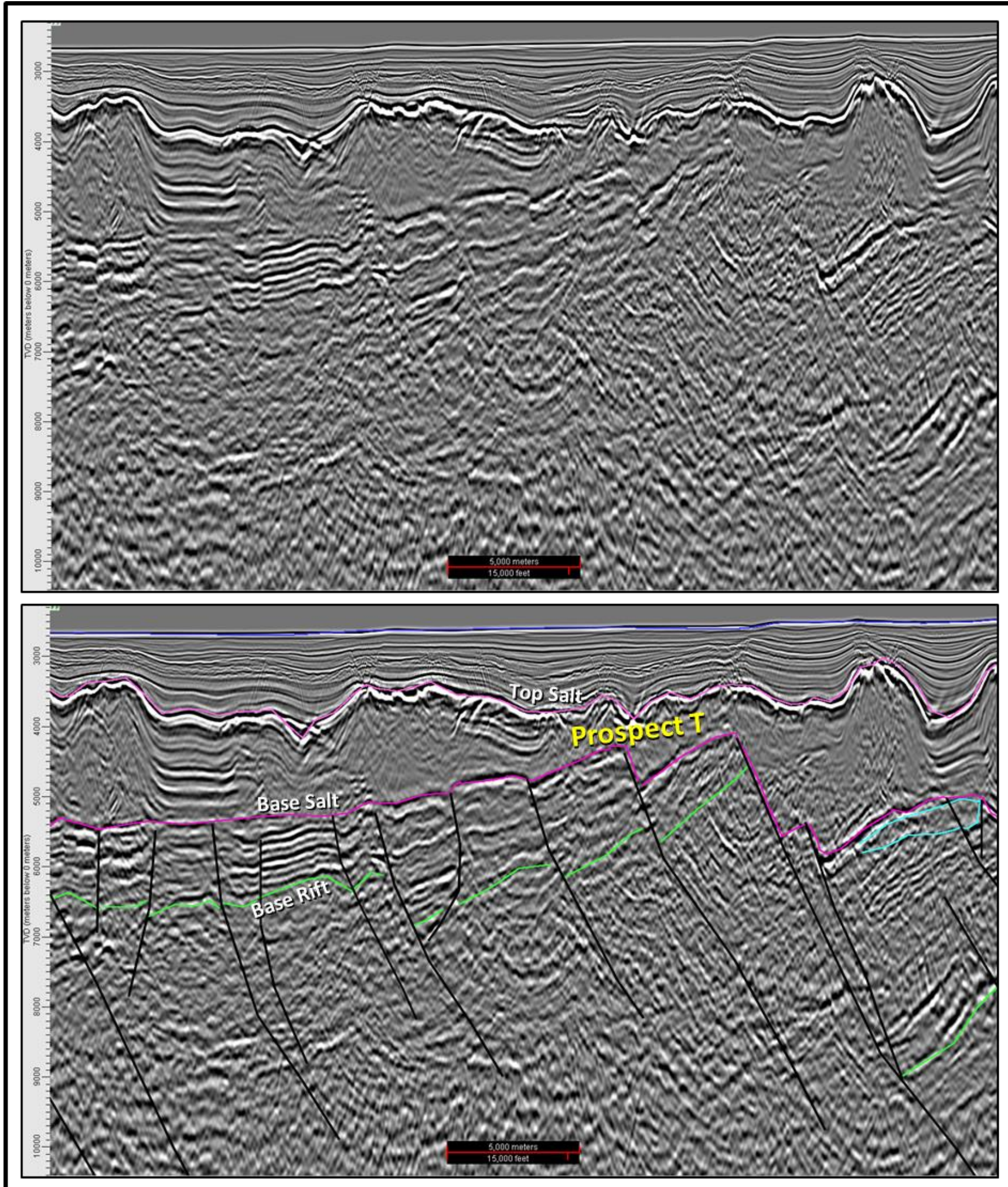

Figure 6 - Depth seismic section displaying a Tupi-look alike three-way closure. Prospect $\mathrm{T}$ is a typical trap related to rotated normal fault blocks of a rift system. The seismic facies situated right below the Base of Salt are interpreted to represent microbialite strata deposited according to the carbonate ramp model (see Figures 2 and 5). 


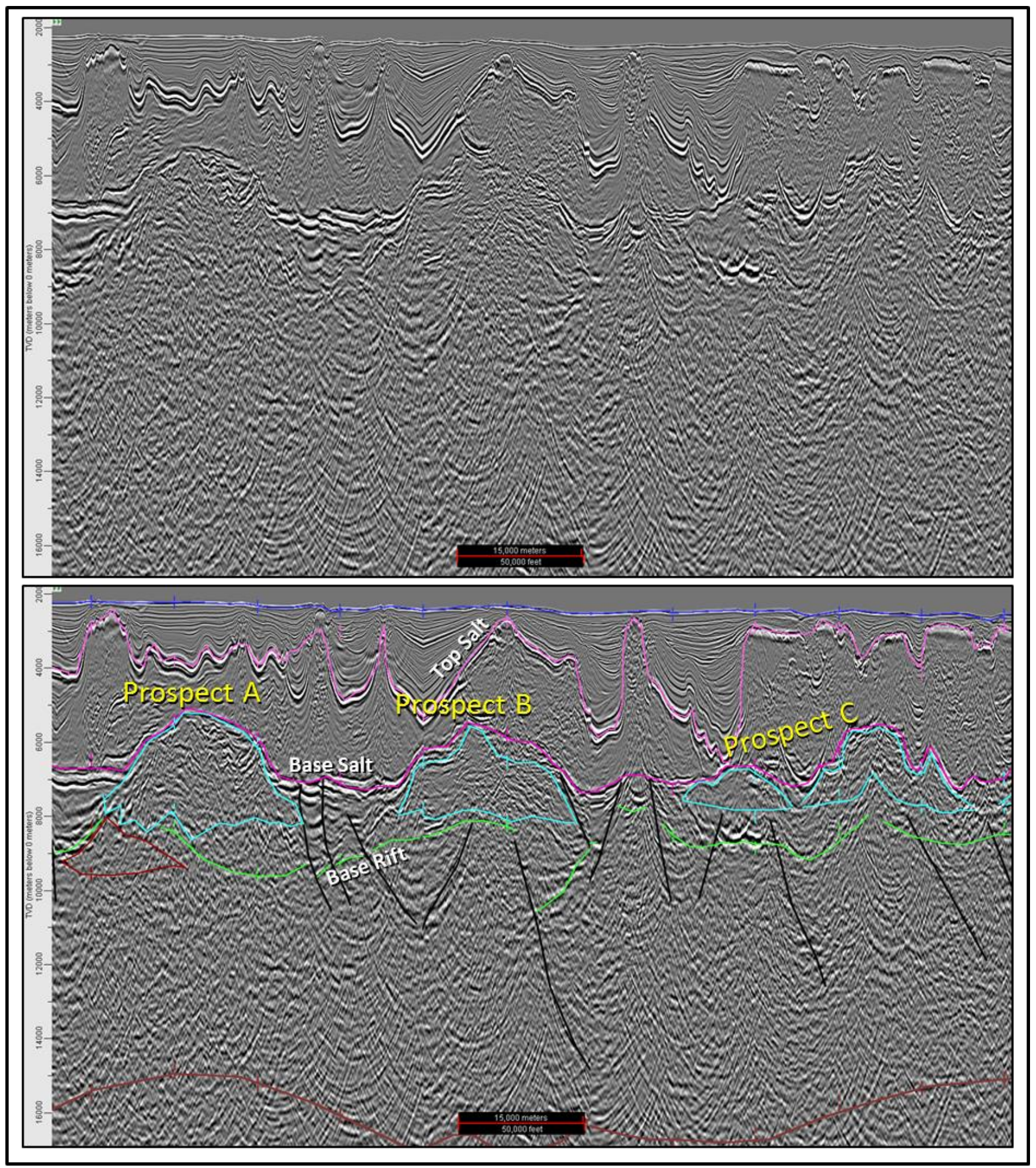

Figure 7 - Depth seismic section displaying three prospects presenting large vertical reliefs. The core of the prospects are conical- to mound-shaped buildups displaying the typical transparent/chaotic seismic facies (blue polygons). Drilling of Prospect A had confirmed the presence of extensive and continuous superb microbialite reservoirs. 